\title{
The Rationality of Faith:
}

The Study of Abraham's Faith in Hebrews 11: 17-19

\author{
Alexander Eduard Theodorus de Walick, ${ }^{1}$ Peni Hestiningrum ${ }^{2}$ \\ ${ }^{1}$ Pentecostal Theological Seminary, Indonesia \\ ${ }^{2}$ Moriah Theological Seminary, Indonesia \\ Email:edu_dewa@yahoo.com
}

\begin{abstract}
In Christian and church life, Faith and Rationality are often opposed to one another. Some Christians reject the aspect of rationality in doing theology, and vice versa. In the Bible presenting Abraham as an example of faith learning through his experiences when he was tempted to offer up Isaac to his only son, Keywords:

he was without a doubt prepared to carry out the commandments he received Faith;

with a thoughtful attitude; that God is able to raise (Isaac) people even from Rationality;

the dead (Hebrews 11: 17-19). The research method used is exegetical study with background and grammatical contexts. The aim of this research is to find the meaning of Abraham's faith in Hebrews 11: 17-19. The result of this research is that the quality of faith is tested and that faith thinks rationally and continuously based on God's word.
\end{abstract}

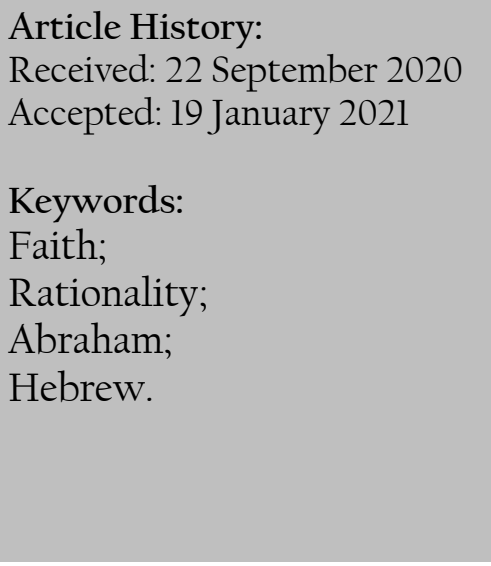
Abraham;

\section{Introduction}

The existence of faith in a person's life is clearly seen when he believes in things he does not see, such as believing that God created this universe. Compare the meaning of this statement by believing that our grandparents also have grandparents and so on and so on so that we understand (= believe) as ancestors. For logical certainty which is more of a rational discourse (ratio), believing in the existence of God and the existence of these ancestors, although in the process has similarities, but differs in terms of responsibility, namely for the desired burden of logical proof of both. This fact, especially for the burden of proof in question, certainly also gives an understanding that basically faith is different from reason (apart from the discussion that both are also related to the burden of moral proof, for moral certainty). However, the real problem is does faith conflict with reason? In the study of the study of its object, cannot the object of faith be rationalized or in other words the process of rationalization of an immanent object always has the potential to manifest intellectualism arrogance? In my mind, it is a matter 
of perspective; that is, how a person puts both faith and reason in shaping his worldview, the outer world and the inner world. ${ }^{1}$

A person's worldview is also confronted with beyond logic problems, namely (logical) realities that are beyond one's ability to reason. Not irrational, but transrational. This term also means that the realities referred to, for logical certainty, have limitations / difficulties for their logical accountability (what about moral responsibility?). Not against logic. On the other hand, a logical conclusion that there cannot be a satisfactory explanation for the desired logical certainty (= solving logical problems). This is clearly different from the irrational term in that a logical account can be given for logical certainty where a particular thing is completely (= valid) absurd. For example, the invalid proposition, the conclusion that dogs lay eggs. Again, if irrational implies a logically definite (= contradictory; rational opposite) meaning, then this is not the case for transrational meanings in the same relationship. Transrational means more logically 'uncertainty' (= cannot be proved to be valid or invalid; true or false) because transrational propositions are clearly beyond reason for logical certainty. The potential for logical uncertainty resides not in the proposition, but in Logic capabilities. Take, for example, propositions for the existence of "spirit peoples" such as demons, ghosts, and so on. Includes propositions from miracle facts. For such examples there is no satisfactory (or not?) Logical certainty but moral certainty (as true or false by priori knowledge; empirical experience). The burden of logical proof on both of them has certain difficulties related to the intended transrational meaning. ${ }^{2}$ This is like the research conducted by Peter Hampson on Credible Belief in "Fides Et Ratio": I Explanatory Constraints in Philosophy, Science and Religion; Santiago Sia on Faith, Reason and Metaphysical Thinking: A Process Response to Fides et Ratio; Elora J. Weringer on Fides et Ratio: The Perpetual Journey of Faith and Reason. ${ }^{3}$

In general, the understanding of true "faith" and based on the Bible is wearing out. The shift is caused by the church in the scale of a local, regional, and national through teachers of God's word who more encouraged people to accept and enjoy the "taste" of fellowship in a momentary pleasure that lulled and only gave the understanding to "just believe in God" for sure. Every thing will go well without based on the correct understanding. This can be interpreted

\footnotetext{
${ }^{\text {l} S a n t i a g o ~ S i a, ~ " F a i t h, ~ R e a s o n ~ a n d ~ M e t a p h y s i c a l ~ T h i n k i n g: ~ A ~ P r o c e s s ~ R e s p o n s e ~ t o ~ F i d e s ~ e t ~ R a t i o . " ~ E-~}$ Theologos, Vol.2, No.2 (2011): 123-124, DOI: 10.2478/vl0154-011-0012-3.

${ }^{2}$ Santiago Sia, Faith, Reason and Metaphysical Thinking: A Process Response to Fides et Ratio: 125-126.

${ }^{3}$ See Peter Hampson, "Credible Belief in "Fides Et Ratio": I Explanatory Constraints in Philosophy, Science and Religion." New Blackfriars Vol.87, No.1011 (2006): 482-504, DOI: stable/43251069; Santiago Sia, "Faith, Reason and Metaphysical Thinking: A Process Response to Fides et Ratio"; Elora J. Weringer, "Fides et Ratio: The Perpetual Journey of Faith and Reason," The Linacre Quarterly. Vol.67, No.4 (2000): 56-77, DOI: 10.1080/20508549.2000.11877591.
} 
that to have faith in God is very easy and instant, so that in endures living in a spiritual life, it is not common for the people not to have the strength to face many challenges which is also prophesied in the Bible itself. They are only "injected" with the motivations and cradles of miraculous phenomena where in fact to be able to experience these things also requires stages of spiritual "growth" with a system of "gradual learning" in faith, and it had to be done by the "church".

In Rome 10:17 it is said "Consequently faith comes from what is heard, and what is heard comes through the preached word of Christ." In other words, faith is not appears all at once, but occurs through a process. Beginning with hearing the Word of Christ or the Word of God, someone who listens to it will experience a process of thought or an interaction between the word of God and oneself

Gradually a person will experience the maturity of life and faith. The process towards maturity will be of great benefit to Christians. From there they will have a strong hold when they are facing with problems as a test leading to a stronger and more mature life in Christianity.

In this study "The Concept and Learning of Abraham's Faith Based on Hebrews 11:17 19", the approach used is a qualitative approach. The research study used is theology by looking at Abraham from the Jewish tradition based on the book of Genesis and the Christian tradition in the Hebrew Scriptures. At the beginning, the author explores the text interpretation regarding faith and reason by paying attention to the context of the text in the book of Hebrews. Then from the results of the interpretation, the writing reflects and implies the results of the interpretation regarding faith and the ratio with the believers.

This article explains that a person who has faith must understand that his faith is not something abstract, but can be a real thing. For example, in the incident Abraham was asked to offer his only son, Isaac in Hebrews 11: 17-19. It says because of faith, when he was tempted - in this position the attitude and action that Abraham took was without hesitation against God's commandment he was ready to do it. And in this series of attitudes and actions Abraham also thought that he dared to do it because in his mind he also knew that God was able to raise even people from the dead, which underlies that there was still a possibility that Isaac would still be resurrected if he had to kill in the procession of sacrifice. Abraham did not think about anything else because his faith was related to the subject of faith itself, God who is able. 


\section{Result and Discussion}

In this section, we will describe in general about Abraham as a central figure in terms of his rational example of faith when he experienced difficult times and choices. Moreover, when he was asked to offer Isaac, his only son to God.

The discussion of Abraham will be highlighted through a Jewish and Christian perspective based on the Hebrew letter. Even though the Jews did not recognize the New Testament, the claim to the nuances and tendencies of the letter opened up the discourse of the Jews that the figure of Abraham was also alive and trusted by those whom they thought did not share their faith.

Apart from the letter to the Hebrews, the New Testament, the review of Abraham drew the writer to look at the information contained in the book of Genesis, cq. Genesis 12-25, which historically tells of Abraham's life journey in relation to God. From the perspective of the Canonical Gospels (the Synoptic Gospels and the Gospel of John), the letters will also be looked at at a glance for information because their names are also written in these books. Also in Paul's letters, Abraham will be viewed as a compilation study and finally, of course from the point of view of the book of Hebrews itself which is concentrated on chapter 11 verses 17 to 19.

As an introduction to Abraham, it is important to note that in their books Andrew E. Hill and John H. Walton explain that Abraham was not introduced as a righteous person, nor was he referred to as a person whose life was different from the world around him. ${ }^{4}$ So Abraham has a background in the life of his country men who do not worship (know) God (YHWH). But it must also be remembered that the direct descent of the Jews is from Abraham. This is important to understand at the beginning so that in the series of learning about his faith in God, a certain conclusion can be drawn. ${ }^{5}$

\section{Abraham in the Jewish Tradition}

Genealogy is an important thing for the nations of this world and genealogy is also very important for the Jewish tradition. The journey of history from time to time can be traced through genealogical records. The genealogy states who our ancestors are and determines who the next heir or successor. Especially in a monarchy system, genealogical records are very

\footnotetext{
${ }^{4}$ Andrew E. Hill dan John H. Walton. 2012. Survey Perjanjian Lama, (Malang, Gandum Mas), 87.

JJoanna Weinberg. “Abraham, Exile, and Midrashic Tradition.” in Martin Goodman, et al., eds., Abraham, The Nations, and The Hagarites: Jewish, Christian, and Islamic Perspectives on Kinship With Abraham, (Leiden: Brill, 2010), $223-$ 234.
} 
important because they state whether a person has the right to occupy the throne or not and in the Jewish tradition this is very strongly attached in their culture. ${ }^{6}$

The Lord God created man in His image and likeness, then chose and set the family institution as the smallest unit in society that developed into a group of people, became a tribe, a nation, one race, and then became one world. When Abraham was called by God, he came out of Ur-Kasdim, came out of his people, came out of his relatives and from his father's house, then went to the land that God would show him - the Promised Land - Abram did not have children. Then God promised offspring that would develop into a great nation, a lineage that God had promised to be a blessing to many nations. Through this line of descend, God will sent forth the Savior come into the world to fulfill His promise since man fell into sin. ${ }^{7}$

In writing the genealogies, Matthew divides them into three broad sections: the genealogy of Abraham - David, the genealogy after David (Solomon) - the Babylonian exile (Jekhonya), the genealogy after the exile (Jekhonya) - Jesus, the Messiah (Christ). Each section consists of 14 generations. The number 14 can be interpreted as $14=(2 x) 7$ (double seven) (NIV), where the number 7 symbolizes perfection (the seventh day of being consecrated by God to become the Sabbath, a hereditary covenant), while $(2 \mathrm{x})$ in the Israelite tradition directly refers to the portion of the birthright / firstborn (each firstborn has inheritance rights double portions). Matthew here wants to take the reader into the nuance of "The Birthright." Jesus is the firstborn, He is the Messiah, the Savior who will lead and carry His people out of savery / occuoation of sin. Thus the birthright of the Israelites as God's chosen people is associated by Matthew with Jesus who was the firstborn (cf. Col. 1:15). This is a correction to the concept of the birthright of the Jewish peoples at that time from the physical side. So, the birthright of God's people must be seen from the perspective of Abraham's descendants (the Seed of Abraham) was Jesus, the Messiah, and not of physically descent (the seeds of Abraham) (cf. Gal. 3:16). Whereas the number 3 is the heavenly, divine, or God's number and in the Old Testament it was always a basic shadow for the God of the Trinity. The history of genealogy of the writing invites the readers at that time, the Jewish people, to look back on their status as God's chosen people who were chosen by means of a promise to Abraham and fulfilled in Jesus, the Messiah, the second Person of the God the Trinity. Without Christ, the "seed of Abraham" did not make the Jewish people different

\footnotetext{
${ }^{6}$ Ronald M. Green. "Abraham, Isaac, and The Jewish Tradition: An Ethical Reappraisal." The Journal of Religious Ethics. Vol.10, No.l (1982): 1-21. DOI: stable/40014943; Joanna Weinberg. "Abraham, Exile, and Midrashic Tradition," 223-234.

${ }^{7}$ U. Bechmann. "Genesis 12 and the Abraham-Paradigm Concerning the Promised Land." Ecumenical Review, Vol.68, No.1 (2016): 62-80. DOI: 10.1111/erev.12199.
} 
from other nations, the Gentiles; they are still sinful peoples, living under slavery to sin, servants of the devil (cf. John 8). ${ }^{8}$

The first 14 genealogy, Abraham - David, is the beginning of the fulfilling path of His chosen people according to the Jewish perspective (Abraham's descendants). Through this passage, Matthew wants to state that Jesus the Messiah is a descendant (the Seed) promised by God, whom through Him all nations will be blessed. An offspring (the seeds) separated by God to escape the worship of false gods through Jesus as the promised seed of Abraham (the Seed). From Ur-Chaldeans, Mesopotamia, a city of the worship of the God of the Moon, Abram was called out into the promised land. Abram was called out of his kinship, culture, and the worship of his god, walking to the promised land merely because of his faith in God and what God has promised. This is the beginning of the path of the true chosen people, a path marked by true faith in God's promises (by covenant and by faith) which contrasts with the concept of salvation at that time [the period of writing of the Gospel of Matthew, ed.]. In this case the name Abraham is very important because Abraham is the father of the believers, the father of the chosen people, the true father of the Jews; to him God promised that he would become the father of many nations, who would follow in Abraham's footsteps to come out of his sinfulness to become one people of God into the promised land. This path of salvation is different from the Jewish concept; one people is not exclusive to the Israelites just physically, but to the chosen people throughout the ages and in all places. The emphasis on the first 14 genealogy is due to related to the name of Abraham in it which is the subject of this paper that is also very closely related to some of the early Jewish traditions. ${ }^{9}$

Since Sarai is not to bear a child, the God's promise that Abraham's descendants would inherit the promised land looked like impossible. Sarai, as was the custom of the time, gave her woman slave who were named Hagar to Abram. When Hagar saw containing the son of Abram, she became arrogant and looked down on Sarai. Sarai drove her into the desert. Hagar was promised that her descendants would be so numerous, "that they cannot be counted because of their number." So Hagar returned and gave birth to her son Ishmael, who was Abram's first son. Hagar and Ishmael were then banished from Abram by Sarai forever (Gen. 21); (NIV 2013, 1554). ${ }^{10}$

${ }^{8} \mathrm{U}$. Bechmann. "Genesis 12 and the Abraham-Paradigm Concerning the Promised Land": 62-80; Ronald M. Green. "Abraham, Isaac, and The Jewish Tradition: An Ethical Reappraisal": 1-21.

${ }^{9}$ Ronald M. Green. "Abraham, Isaac, and The Jewish Tradition: An Ethical Reappraisal": 1-21; see Shari L. Lowin. "Abraham in Islamic and Jewish Exegesis." Religion Compass, Vol.5, Iss.6 (2011): 224-235. DOI: 10.1111/j.17498171.2011.00274.x.

${ }^{10}$ Shari L. Lowin. "Abraham in Islamic and Jewish Exegesis": 224-235. 
In Christianity and Jewish tradition it is stated that those who are called the descendants of Abraham are from Isaac, this is in accordance with the verse in the book of Genesis 21:12 But God said to Abraham, "Do not be up set about the boy or your slave wife. Do all that Sarah is telling you because through Isaac your descendants will be counted. Myers explains;

Although Ishmael was born before Isaac, he was a boy born to a woman slave Hagar, an Egyptian woman who became a slave to Abraham's family, a servant to Sarah. According to the customs at that time, what was counted as a child was from the legal wife, in this case Isaac was the most entitled to be called the heir. ${ }^{\text {ll }}$

\section{Abraham in the Image of Genesis 12-25}

Abraham's original name was Abram, and he was the son of Terah, from Ur of the Chaldeans. Abram was born when Terah was 130 years old (remembering Abram was 75 years old when Terah died at 205 years old). Then Terah took Abram, his son, and his grandson, Lot, Haran's son, and Sarai, his son-in-law, Abram's wife, his son; he went with them from UrChaldeans to go to the land of Canaan, and they came to Haran, and dwelt there. Terah is 205 years old; then he died in Haran. After that, Abram and his wife Sarai, Lot (son of Abram's brother, Haran), and all of his followers, then went to Canaan. ${ }^{12}$

Abram was 75 years old, when he left Haran. The LORD commanded Abram to go to "the land that I will show you", and promised to bless him and make him a great nation. Believing this promise, Abram went to Shechem, and received a new promise that the land would be given to his descendants. After building an altar to commemorate this covenant, he went and pitched tents between Bethel and Ai, where he built another altar and "invoked the name of the LORD. The genealogy according to the book of Genesis; Abraham was a descendant of Shem and son of Terah, the ancestor of the Jewish nation. and the Gentiles (Gen. 17: 5). His faith was very firm and he was known as a 'friend of God' (2 Chr 20: 7). His biography is presented in Gen. 11: 26-25: 10, and a summary in Acts 7: 2-8. A list of his direct descendants through his sons Isaac and Ishmael is found in Genesis 25: 11-19. His life was made an example of faith in God (Hebrews 11: 8-12) by Jews, Christians, and Muslims, and in particular by Jews and Christians through verses 17-19. This (regarding genealogy) needs to be raised because the Jewish tradition is very strong holding this culture, especially later with regard to "agreements and inheritance". 13

\footnotetext{
${ }^{11}$ Benjamin Myers. Salvation in My Pocket: Fragments of Faith and Theology. (Eugene, OR: Cascade, 2013), 5.

${ }^{12}$ David J. Zucker. "Abraham, The Years of Frustration: Genesis 13-14 and 15 as a Literary Unit." Biblical Theology Bulletin: Journal of Bible and Culture. Vol.48, No.l (2018): 3-9. DOI: 10.1177/0146107917746575

${ }^{13}$ Kris Sonek. "The Abraham Narratives in Genesis 12-25." Currents in Biblical Research. Vol.17, No.2 (2019): 158-183. DOI: 10.1177/1476993X18809846.
} 
Between Bethel and Ai, he stayed for some time, until there was a dispute between his shepherds and Lot's shepherds. Abram suggested to Lot that they separate, and allowed his nephew to choose first. Lot chose fertile land east of the Jordan, while Abram, having received another promise from the LORD, went to Mamre, near Hebron, and built another altar to the Lord. In the story about Lot and the destruction of Sodom and Gomorrah, Abram appears when he pleads with the Lord to have mercy on Sodom. At that time, the LORD told Abram that He would come down and see if they really had acted like the complaints of those who had reached Him or not. ${ }^{14}$

The etymology of the name Abram (Hebrew 'avram, Gen. 11: 27-17: 5) is uncertain, but may mean' glorified father 'and is similar to Western Semitic names such as Abiram. As promised in the sacred covenant between God and Abram and his descendants from generation to generation, his name was changed to Abraham ('avraham) which means' father of a great number of nations' (Gen 17: 5). This has been thought of as another or a dialectical form of Abram (h denotes the long vowel). The name Abraham was given to Abram (and Sara to Sarai) at the same time as the circumcision covenant (Gen 17: 5,15), which is practiced in Judaism and Islam to this day. Now Abraham is promised not only that he will have many descendants, but also that these descendants will come from Sarah, and also that the land in which he lives will belong to his descendants. This covenant was fulfilled through Isaac, even though God promised that Ishmael would be a great nation too. The circumcision covenant (unlike other promises) has two sides and is conditional: if Abraham and his descendants fulfilled their promise, the LORD would be their Lord and give them the land. ${ }^{15}$

Abraham was born in Ur-Chaldeans, where he lived with his father, Terah, and his brothers, Nahor and Haran, as well as his nephew, Lot. He is married to Sarai. After Haran died, he moved to the land of Haran with his wife, father and Lot; then Terah died in Haran (Gen 11: 26-32). By the call of God, Abraham at the age of 75 years left Haran with Lot and via Shechem and Bethel entered Canaan (12: 1-9). The danger of starvation forced him to go to Egypt via the Negeb. In Egypt he and Sarai were able to escape from Pharaoh, only because God brought plague on Pharaoh (12:10-20). Upon his return to Bethel, a dispute arises between Abraham and Lot, which ends with Abraham's wisdom to allow Lot to choose the fertile Jordan Valley for grazing his livestock (13: 1-14). God promises Abraham to own the entire land from the Euphrates River to the southwest, and Abraham back to Mature near Hebron (13: 15-18).

\footnotetext{
${ }^{14}$ Helyer, 1983, 77-88; Kris Sonek. "The Abraham Narratives in Genesis 12-25": 158-183.

${ }^{15}$ Kris Sonek. "The Abraham Narratives in Genesis 12-25": 158-183; David J. Zucker. "Abraham, The Years of Frustration: Genesis 13-14 and 15 as a Literary Unit": 3-9.
} 
Because of the oppression and plunder of Sodom and Gomorrah by a coalition of four kings under Chedorlaomer, Abraham and his men and his Amorites from Mature, pursued and defeated the robber near Damascus and rescues all the loot (14:1-16) on the way home Abraham receives a blessing from Melchizedek, a priest of Most High God (14:17-24). ${ }^{16}$

Due to severe famine, Abram and his family went to Egypt (Gen. 26:11, 41:57, 42: 1), where he feared that his wife's beauty would captivate the Egyptians. Therefore he lied that Sarai was his sister. This did not save him from Pharaoh, who took him to be his wife and gave Abram a lot of cattle and slaves. But when the Lord plagued Pharaoh, Abram and Sarai left Egypt. ${ }^{17}$

Abraham, being childless, made Eliezer, a slave born into Abraham's slave family, his heir. But now Abraham received a special guarantee from God, that he himself would have a son. Through this child a nation will emerge in the future. This special guarantee and ownership of land are determined by an agreement (15). Meanwhile Sarai gave him Hagar, as a concubine, with whom Abraham, now 86 years old, had a son named Ishmael. Hagar, as a result of ridiculing Sarai's sterility, was expelled and went to the wilderness but was released by the Angel of the Lord (16).

Sometime after Isaac's birth, Abraham was commanded by God to sacrifice Isaac on Mount Moriah. Before Abraham could obey this, an angel stopped him and provided a substitute sacrifice and then sacrificed a ram. In return for this obedience he received another promise that God would make his descendants "as numerous as the stars in the sky and like the sand by the sea", and that they "would occupy the cities of their enemies." 18

Sara died at an advanced age, 127 years. At that time, Isaac was 36 years old and unmarried. To bury his wife, Abraham bought a field and a cave called Makhpela's cave from Efron son of Zohar the Hittite. After that Abraham buried his wife Sarah in the cave of the Makhpela field, east of Mamre, namely Hebron in the land of Canaan. After that Abraham also took a wife, whose name was Ketura. The woman gave birth to him Zimran, Yoksan, Medan, Midian, Isybak and Suah. Yoksan was the father of Sheba and Dedan. The descendants of Dedan were the Assyrians, the Letushites and the Leumites. The sons of Midian were Efa, Efer, Enoch, Abida and Eldaa.

As an inheritance Abraham gave all his possessions to Isaac, but to his children which he obtained from his concubines he gave gifts; Then he ordered them, still while he was alive, to leave his son Isaac and go east to the Land of the East.

\footnotetext{
${ }^{16}$ Joseph Blenkinsopp. "Abraham as Paradigm in the Priestly History in Genesis." Journal of Biblical Literature, Vol.128, No.2 (2009): 225-24l. DOI: 10.2307/25610180.

${ }^{17}$ David J. Zucker. "Abraham, The Years of Frustration: Genesis 13-14 and 15 as a Literary Unit": 3-9.

${ }^{18}$ Shari L. Lowin. "Abraham in Islamic and Jewish Exegesis": 224-235.
} 
Abraham reached the age of 175 years and then he died. And he died when his hair was white, and was old and long ages, he was gathered to his ancestors. And his sons Isaac and Ishmael buried him in the cave of Makhpela, in the field of Ephron son of Zohar the Hittite, the field which is to the east of Mamre, which Abraham bought from the Hittites. buried there Abraham and his wife Sarah. ${ }^{19}$

In the book of Genesis, we can explore the implicit "character of Abraham" which is related to his faith, which is contained in the verse by verse as follows; Abraham expressed his belief in Almighty God (Gen.17: 1), eternal (21:33), Most High (14:22), who possesses (God) heaven and earth $(14: 22 ; 24: 3)$, and a just Judge over all nations (15:14) and all mankind (18:25). For him God is just (18:25), wise (20: 6), true and just (18:19), generous (19:19), and forgiving (20: 6). Abraham accepted God's punishment for sin (18:19; 20:11) but spoke with God on behalf of Ishmael (17:20) and the sinful Lot (18:27-33). Abraham associated with God in intimate fellowship (18:33; 24:40; 48:15), and was given a special revelation in the form of a vision (15: 1) and God pleased to visit him in human medium (18: 1) or angelic form ('messenger') (22:11, 15). Abraham worshiped God, and called God by the Name of God (13:4) and built an altar for this purpose $(12: 8 ; 13: 4,18)$. His monotheism clearly contradicted the polytheism of his ancestors (Josh. 24:2). ${ }^{20}$

Abraham's faith is perhaps most striking in terms of his obedience and readiness to do anything more than the command of the Lord. By faith he left Ur-Chaldeans (Gen. 11:31; 15: 7), an action which Stephen emphasized (Acts 7: 2-4). Likewise he was led to leave Haran (Gen. 12: 1, 4). By faith he received the half-wanderer or 'traveler' life, even though the land of Canaan had been promised to him $(13: 15 ; 15: 18)$. He experienced only a part of the overall fulfillment of the agreement, namely occupying a small plot of land in Makhpela and obtaining rights near Beersheba. The most severe trial of his faith, is that he was asked to sacrifice Isaac, his real son who humanly Isaac was the only way for God's covenant to be fulfilled completely. His faith was founded on trusting in God's power, if necessary, to raise his son from the dead (Gen. 22:12, 18; Heb 11:19).

If we examine the whole life of Abraham mentioned above, there are four important stages of separation in his life. The four stages show the stages of faith of saints,

The first separation_was separation from land and relatives, as well as separation from Terah, his father (Gen 12: 1; Acts 7: 2-4).

\footnotetext{
${ }^{19}$ S.D. Snyman. "Abraham in Galatians and in Genesis." Acta Theologica. Vol.33, No.2 (2013): 148-163. DOI: 10.4314/actat.v33i2.9.

${ }^{20}$ David J. Zucker. "Abraham, The Years of Frustration: Genesis 13-14 and 15 as a Literary Unit": 3-9; Joseph Blenkinsopp. "Abraham as Paradigm in the Priestly History in Genesis": 225-241.
} 
Ur-Chaldeans was the place where Abraham's ancestors worshiped idols (Josh. 24: 2, 15). Abraham leaving Ur-Chaldeans shows separation from the world which is the first stage of faith. Ur-Chaldeans, which is located in the southeast of Baghdad, is a fertile land that was the center of ancient civilization and also a center of idolatry. Idolatry had reached its peak in Abraham's time so Abraham's father Terah was more attracted to idolatry than worshiping the true God. $^{21}$

At that time God commanded Abraham, "Go out of your country and from your kinsmen" (Acts 7: 3). Abraham then left the idol city Ur-Chaldeans with his father Terah, and arrived at Haran. But Terah was seduced by the comfortable and pleasant life of Haran, a stopover city, and settled there. Finally, when Abraham was 75 years old, God called him a second time. Now God commands Abraham not only to leave his country and relatives, but also his father's house (Gen 12: 1). This commandment is a direct and strict command. Such orders were given because Abraham did not fully obey God's commands when he was called out of Ur-Chaldeans. Genesis 12: 4-5 records that Abraham could enter Canaan only after obeying God's command to separate completely from his father's house. This is certainly difficult because Abraham lived in a patriarchal society (paternal line), so it was difficult for him to reject his father's will and to leave him. When Abraham left Haran at 75 years of age, Terah was 145 years old and still alive (Gen 12: 4; 11:26). As the eldest son in charge of a family, his heart must have been very heavy when he had to leave a father who was 145 years old. Therefore, the statement in Acts 7: 4, "Abraham came out of Haran after his father died" shows how great the decision of Abraham's faith was to be willing to go to follow God's word. The word "died" is used in Acts 7: 4, in Greek is apothnēsko, used with a symbolic meaning (1 Cor. 15:31). This word indicates that Abraham was totally separated so that his love for his father did not last (Luke 14:26). Abraham broke off his love for his father at the age of 75 (Terah was 145 years old) and left Haran. Sixty years later Terah died in Haran at the age of 205 (Gen 11:32). Abraham had triumphed over all the pain of separation and followed God's word by faith alone (Gen 12: 4). ${ }^{22}$

The second separation_is separation from Lot (Gen 13). If we look at Genesis 13: 10-11, it can be seen that Lot was a person full of worldly lusts. God also separated Abraham from Lot.This separation shows the separation from worldly conditions and the continuing uncertainty even though it has been separated and expelled from the world. Genesis 13: 11-12 writes; "So Lot chose

\footnotetext{
${ }^{21}$ Abraham Park. Silsilah di Kitab Kejadian. (Jakarta: Grasindo \& Yayasan Damai Sejahtera Utama, 2010), 232; S.D. Snyman. "Abraham in Galatians and in Genesis": 148-163; Joseph Blenkinsopp. "Abraham as Paradigm in the Priestly History in Genesis": 225-241.

${ }^{22}$ Abraham Park. Silsilah di Kitab Kejadian, 232; David J. Zucker. "Abraham, The Years of Frustration: Genesis 13-14 and 15 as a Literary Unit": 3-9.
} 
for him the whole Jordan Valley, so he went to the east and they parted company." Abram settled in the land of Canaan, but Lot settled in the cities of the Jordan Valley and camped near Sodom. "When Abraham and Lot parted company, Lot chose the entire Jordan Valley to Zoar because of the abundance of water and he saw it as beautiful as God's garden. This action shows that Lot is full of worldly and materialistic passions. Genesis 13:10 writes; "Then Lot looked up and saw that the whole Jordan Valley was well watered, as the garden of the LORD, as the land of Egypt, even to Zoar. This happened before God destroyed Sodom and Gomorrah. "Lot, Abraham's nephew is the only relative who has accompanied Abraham through difficult times along the way from when he left Ur-Chaldeans until he arrived and settled in the land of Canaan, a foreign land, the land of the Gentiles. When Abraham had to part with Lot, who always accompany and becoming as his backbones, there must be pain in Abraham. But it was spent by Abraham lived there in the form of obedience to God and His word. ${ }^{23}$

Third Separation is separation from Ishmael (Gen. 21). After Isaac was born as a "son of covenant", Abraham separated from Ishmael, the firstborn son born to Hagar from human thought (Gen. 21: 10-14). This separation symbolizes the stage of our faith which gives up all our plans and abilities to submit to God's great will. This separation is a process of self-denial. In Genesis 17:18 Abraham pours out his heart to God, "Ah, if Ishmael may live before You!" also in Genesis 21:11 states, "This was very annoying to Abraham because of his son." These verses show that Abraham had poured out great love for about 17 years to his firstborn son Ishmael. Even though Abraham loved his son, but he decided without hesitation to obey the Lord's commands. Abraham did it all by the Lord's will to separate from the child with his mother. As a human being, separation from Ishmael must be a very great pain throughout life Abraham as a father. Once again all he did was out of obedience to the Lord and His word. ${ }^{24}$

The fourth separation is from Isaac (Gen 22). After God ordered Abraham to part with Ishmael, God also commanded Abraham to offer up Isaac as a burnt offering. Abraham gave his only son as a burnt offering to God according to this command (Gen. 22: 1-12). Indeed, God saved Isaac, but this event was a separation for Abraham because he had to offer his beloved and most precious possession and his best to God without a doubt (Gen 22: 16-17). For Abraham this separation was equivalent to death. This separation is a separation that shakes the the very

\footnotetext{
${ }^{23}$ S.D. Snyman. "Abraham in Galatians and in Genesis": 148-163; Joseph Blenkinsopp. "Abraham as Paradigm in the Priestly History in Genesis": 225-241; Ronald M. Green. "Abraham, Isaac, and The Jewish Tradition: An Ethical Reappraisal": 1-21.

${ }^{24}$ Abraham Park. Silsilah di Kitab Kejadian, 234; S.D. Snyman. "Abraham in Galatians and in Genesis": 148-163; Joseph Blenkinsopp. "Abraham as Paradigm in the Priestly History in Genesis": 225-241; Ronald M. Green. "Abraham, Isaac, and The Jewish Tradition: An Ethical Reappraisal": 1-2l.
} 
foundations of the base of his life. ${ }^{25}$ Abraham was not only required to break his ties with Ishmael, the son born to him according to the flesh, but also with Isaac the son of covenant. Isaac was the only heartbreak for Abraham at that time, but he managed to overcome the trials of God with absolute trust in Him even though the trials were very difficult to understand. This belief is an attitude of a person who is mature in faith who returns all the greatest blessings of God to Him, and who ultimately recognizes that these blessings belong to God. ${ }^{26}$

\section{Abraham in the Hebrews}

Regarding Abraham in Hebrews, we will definitely turn to chapter 11 where the name Abraham with "summary of the journey of faith" is so predominantly told. This chapter is often referred to as the "crown of the Hebrews" which speaks of faith. Many good things about faith and examples of faith that are told in this letter to Hebrews, can even help readers to focus on their faith in order to get what is promised. However, this paper focuses our discussion on a figure of faith known as the "Father of the Believers", that is Abraham, which is more specifically focused on Hebrews 11:19 "Because he thought that God was able to raise people even from among the dead. And from there he seemed to have received it back." s a crown, of course this chapter has its own position in Hebrews because it is an important part of the series of decrees of faith in God Almighty. Faith is something important, because it is faith that keeps us attached and loyal to God. By faith, we can survive the journey and the battles of our life. However, because the hope of faith is often a hope that contradicts or opposed by the instincts of human tendencies, the writer to the Hebrews feels it is necessary for us to learn from biblical characters who lived in faith so that we imitate them, learn from them, and then see whatever is possible. sometimes we have to pay a heavy price for our faith, we still get a fair share. ${ }^{27}$

Abraham is a very important figure, who is highly respected by both Muslims, Christians and Jews. Abraham is known to the Jews as the first character in the Old Testament Bible to worship Yahweh God and really know who Yahweh God is personally. When Abraham was called to go to the land that God promised to be his he obeyed. He left even though he did not

\footnotetext{
${ }^{25}$ Abraham Park. Silsilah di Kitab Kejadian, 235; S.D. Snyman. "Abraham in Galatians and in Genesis": 148-163; Joseph Blenkinsopp. "Abraham as Paradigm in the Priestly History in Genesis": 225-24l; Ronald M. Green. "Abraham, Isaac, and The Jewish Tradition: An Ethical Reappraisal": 1-21.

${ }^{26}$ Abraham Park. Silsilah di Kitab Kejadian, 236; S.D. Snyman. "Abraham in Galatians and in Genesis": 148-163; Joseph Blenkinsopp. "Abraham as Paradigm in the Priestly History in Genesis": 225-24l; Ronald M. Green. "Abraham, Isaac, and The Jewish Tradition: An Ethical Reappraisal": 1-21.

${ }^{27}$ Joel N. Lohr. "Abraham the Missionary? The Call of Abraham in Judaism, Christianity, and Islam." Journal of Inter-Religious Studies, Iss.13 (2014): 67-71. https://scholarlycommons.pacific.edu/ed-facarticles/31; Danijel Berković. "Jesus and Abraham. The Role and Place of Abraham in Jesus' Teaching." Kairos : Evangelical Journal of Theology, Vol.7, No.2 (2013): 121-12. https://hrcak.srce.hr/215524.
} 
know the place he was going to go to. If we imitate Abraham's faith, faith means holding on to a future that is not yet known. Abraham had to leave all his comfort and stability to go to a strange place he did not know. He just had to keep going. Even though his heart may be full of questions about where he is going and what will happen to him there, he still goes. This is different from our instinctive tendencies. Our first instinctive tendencies are like the adage that says don't let go of the bird in hand for expecting the bird that is still flying high in the sky. Even if the flying bird is much more attractive, do not let go of the one in your hand first. Abraham in his attitude of faith was not like that at all. However, this also cannot be equated with a life of recklessness or without calculation, but a life based on a belief that that is what God wills. If we try to live like that, we may have to bear very heavy risks. ${ }^{28}$

Like Abraham on his journey, he had to face hunger, had to flee to Egypt, his wife was about to be taken by the king, he grew old and died, but still had no children. Until he died, Abraham did not own the land that God promised him, instead he had to buy a piece of land from someone else. Those who have faith often do not enjoy the promises God gave them, as did Abraham. Many of them died as people who did not get what was promised. This often marks the life journey of a believer. But faith becomes very meaningful even at such times, who continue to believe that if God says it or gives the promise, no matter what the reality appears, we still believe that God is true. For this reason, Hebrews 1l: 1 describes faith as the basis of things hoped for and evidence of things not seen. ${ }^{29}$

Maybe what we hope for has not been seen, even what is seen now is contrary to what was promised. However, faith itself already believes as if we have got it. Therefore, faith also means patience, patience in holding on to God's promises. Patience is like Abraham who even though he died he still did not get the land that was promised to him, he still kept God's promise. Faith is so important, but faith is also so hard. Living in faith is not something easy. Faith means having the courage to hold on and live only according to God's promises. That's hard already. It is difficult for us to live only based on God's promises, on something that is not visible. Even though we tend to want to live something certain. However, faith invites us to enter a life as if without certainty. Only the leading hand of God alone is one only certainty. ${ }^{30}$

Abraham was a stranger, a foreigner as long as he lived on earth. Being a foreigner is certainly not fun. Foreigners are people who have to live far from their homeland and live in a

\footnotetext{
${ }^{28}$ Andrew Chinpeng Ho. "A Paragon of Faith? Doubting Abraham." Themelios, Vol.42, Iss.3 (2017): 452-464.

${ }^{29}$ S.D. Snyman. "Abraham in Galatians and in Genesis": 148-163; Danijel Berković. "Jesus and Abraham. The Role and Place of Abraham in Jesus' Teaching": 121-12.

${ }^{30}$ Joel N. Lohr. "Abraham the Missionary? The Call of Abraham in Judaism, Christianity, and Islam": 67-71; Andrew Chinpeng Ho. "A Paragon of Faith? Doubting Abraham": 452-464.
} 
foreign land. In the days of the Hebrews, people lived in a culture where property was something special, which made a person feel bound. Maybe this is different from today's modern society which is characterized by very high mobility or displacement, and is no longer too tied to the land of origin. Abraham was willing to live as a foreigner, as a foreigner because of his faith. Abraham probably had to face a very difficult life in this world. Even though he had to be willing to lose a lot of pleasure and gain, he never returned to where he came from. Faith means moving on. This world is seen only as a temporary place, so that he does not place all of his hopes in this world, but in God, in something to come that is eternal. ${ }^{31}$

Therefore, Abraham was also able to do something that might have been impossible for us, to offer up his only son, Isaac. This act of Abraham is actually the culmination of the impossibility of faith itself. This is the most dramatic example of Abraham's "act of faith." Faith means that we are willing to offer what is most precious to God. This is very difficult to do. If we just offer the leftover part, it is easy to do. But if we have to offer the most beautiful, the best, maybe we won't be able to. To be able to do that, we must learn from Abraham, who must fully realize that everything that is in us including ourselves, our own life belongs to God. When we realize that everything belongs to God, and not ours, we can give it willingly when God asks him back. By doing so, God will be the only one in our life. ${ }^{32}$

Faith also means that we can accept sincerely things we may not be able to understand. Abraham may not have understood why God told him to sacrifice Isaac, but he did it anyway. Not because he had to to, but because God commanded him. According to the writer to the Hebrews, Abraham believed that even if Isaac died, God still had the power to raise him again. Abraham could accept what he could not understand because he knew that God always has a way out (Hebrews 11:19 "Because he thought,......"). Therefore, Abraham was able to remain faithful, obedient, whatever the situation.

\section{Conclusion}

Learning about rational faith from a faith figure who is also called "the father of believers", that is Abraham. So it can be concluded that the events and experiences of Abraham's faith when he had to make a decision in a test of faith which could be said was not light because he had to give up something valuable, he could live without doubt or doubt. Instead, by being

\footnotetext{
${ }^{31}$ S.D. Snyman. "Abraham in Galatians and in Genesis": 148-163; Danijel Berković. "Jesus and Abraham. The Role and Place of Abraham in Jesus' Teaching": 121-12.

${ }^{32}$ Andrew Chinpeng Ho. "A Paragon of Faith? Doubting Abraham": 452-464.
} 
loyal to his Lord, he did it obediently. This event is illustrated briefly and clearly in the relevant verse from the writing of this scientific work, in Hebrews 11: 17-19.

Abraham was able to perform these acts of faith faithfully and obediently in an attitude of willingness because of "he thought" which in the KJV edition of the English Bible is written as "accounting" or in Greek it is written as "Logizomai" which means "calculating or concluding.".

What did Abraham calculate or conclude to enable him to exercise his faith so faithfully and in obedience to his Lord? Sure to know this one has to look at the whole journey of Abraham's life which definite walked with his Lord. So many "words of God" that Abraham heard and received directly from God during the course of his life, and of course this is what formed his character both directly and indirectly to obey and be loyal to God. Therefore, of course, this "word of God" was taken into consideration in him to enable him to carry out "calculations" or even "conclude" a command (the word of God) that came to him. His faith is awakened from the word of God (Romans 10:17), because it is either directly or indirectly from knowing God's words that faith appears and grows even to perfection. Indeed, in Hebrews 12: 2, it is explained that faith becomes perfect if our eyes are focused on Jesus alone. However, for the church today (both personally and as a unit) of course the person of Jesus is no longer there. In the existence of His presence as when He was still in ministry on this earth. And as a substitute is the word of God that is in the built church in the form of a well canonized book, namely the Bible with its innerancy. (John 1: 1, 14)

Looking at the Word of God by holding on to Him, in living this life we will not be ashamed (Psalm 199: 5-6). Holding on to Him, of course, by reading it, studying it and being able to interpret it and apply it in life. And that is what happened to Abraham so that he was able to "Logizomai" or summarize God's words or commands that came to him and immediately did it without any doubt. There is a strength of faith that cannot easily be shaken if the growth of faith has reached this level. And faith in such a position must occur in the "church of God" in the last days.

\section{Bibliography}

Bechmann, U. "Genesis 12 and the Abraham-Paradigm Concerning the Promised Land." Ecumenical Review, Vol.68, No.1 (2016): 62-80: https://doi.org/10.111l/erev.12199.

Blenkinsopp, Joseph. "Abraham as Paradigm in the Priestly History in Genesis." Journal of Biblical Literature, Vol.128, No.2 (2009): 225-241. DOI: 10.2307/25610180. 
Berković, Danijel. "Jesus and Abraham. The Role and Place of Abraham in Jesus' Teaching." Kairos: Evangelical Journal of Theology, Vol.7, No.2 (2013): 113-130. https:/hrcak.srce.hr/215524.

Green, Ronald M. "Abraham, Isaac, and The Jewish Tradition: An Ethical Reappraisal." The Journal of Religious Ethics. Vol.10, No.1 (1982): 1-21. DOI: stable/40014943.

Hampson, Peter. "Credible Belief in "Fides Et Ratio: I Explanatory Constraints in Philosophy, Science and Religion." New Blackfriars, Vol.87, No.10ll (20lz6): 482-504, DOI: stable/43251069.

Ho, Andrew Chinpeng. "A Paragon of Faith? Doubting Abraham." Themelios, Vol.42, Iss.3 (2017): 452-464.

Lohr, Joel N. "Abraham the Missionary? The Call of Abraham in Judaism, Christianity, and Islam." Journal of Inter-Religious Studies, Iss.13 (2014): 67-71. https://scholarlycommons.pacific.edu/ed-facarticles/31.

Lowin, Shari L. "Abraham in Islamic and Jewish Exegesis." Religion Compass, Vol.5, Iss.6 (2011): 224-235. DOI: 10.1111/j.1749-8171.2011.00274.x.

Myers, Benjamin. Salvation in My Pocket: Fragments of Faith and Theology. Eugene, OR: Cascade, 2013.

Park, Abraham. Silsilah di Kitab Kejadian, Jakarta: Grasindo \& Yayasan Damai Sejahtera Utama, 2010.

Santoso, Agus. Dabar; Tata Bahasa Ibrani, Bandung: Bina Media Informasi. 2011.

Santoso, Agus. Logos: Tata Bahasa Yunani Koine, Bandung: Bina Media Informasi, 2011.

Sia, Santiago. Faith, Reason and Metaphysical Thinking: A Process Response to Fides et Ratio. E-Theologos, Vol.2, No.2 (2011): 123-132, DOI: 10.2478/v10154-011-0012-3.

Snyman, S.D. "Abraham in Galatians and in Genesis." Acta Theologica. Vol.33, No.2 (2013): 148-163. : DOI: 10.4314/actat.v33i2.9.

Sonek, Kris. "The Abraham Narratives in Genesis 12-25." Currents in Biblical Research. Vol.17, No.2 (2019):158-183. DOI: 10.1177/1476993X18809846.

Weinberg, Joanna. “Abraham, Exile, and Midrashic Tradition.” in Martin Goodman, et al., eds., Abraham, The Nations, and The Hagarites: Jewish, Christian, and Islamic Perspectives on Kinship With Abraham, (Leiden: Brill, 2010), 223-234.

Weringer, Elora J. "Fides et Ratio: The Perpetual Journey of Faith and Reason," The Linacre Quarterly. Vol.67, No.4 (2000): 56-77, DOI:10.1080/20508549.2000.11877591. 
Zucker, David J. "Abraham, The Years of Frustration: Genesis 13-14 and 15 as a Literary Unit." Biblical Theology Bulletin: Journal of Bible and Culture. Vol.48, No.l (2018): DOI: $10.1177 / 0146107917746575$. 